\title{
Comparative Evaluation of Strength and Electrical Activity of the Pectoralis Major Muscle During Bench Press Exercise in Horizontal, Incline and Decline Modalities
}

ORIGINAL

\begin{abstract}
Elvis Costa Crispiniano', Manuela Carla de Souza Lima Daltro², Elicarlos Marques Nunes ${ }^{3}$, Rui Araújo Junior4, Maércio Mota de Souza ${ }^{5}$, Thiago Alves Munguba ${ }^{6}$, Michele Baffi Diniz ${ }^{7}$
\end{abstract}

\section{Abstract}

Introduction: The sports have great meanings in adult health. The contributions of the practices of physical exercise has been huge.

Objective: The aim of this study was to evaluate the strength and the electrical activity of the pectoralis major muscle during bench press exercise on a machine in horizontal, incline and decline positions.

Methodology: The sample was constituted of 20 male subjects with mean age of $23.2 \pm 0.9$ years old. They underwent electromyographic evaluation of the three parts of the pectoralis major muscle, performing the horizontal bench press exercise with or without lumbar rectification, and they also performed the incline and decline modalities. The exercises consisted of three repetitions with Maximal Voluntary Isometric Contraction (MVIC) lasting 5 seconds each, with one-minute interval between them, followed by verbal commands of the researcher. The muscle strength values expressed in kilograms (kg) were analyzed using Miograph 2.0 software and the electromyographic signal was normalized by MVIC and extracted from a three-second window. Inferential statistics was applied by Friedman and Multiple Comparisons non-parametric tests $(p<0.05)$.

Results: The electrical activity of the clavicular and sternocostal parts of the pectoralis major muscle showed no significant difference between the four modalities of bench press exercises. However, the electrical activity of the lower part in the incline bench press exercise
1 Physiotherapist, Masters in Health Sciences; Teacher at College Maurício de Nassau e Integrated College, Patos (PB), Brazil.

2 Physiotherapist. Master in Health Sciences. Teacher, Department of Physical Therapy of Patos Integrated College (PB), Brazil.

3 Nurse. Master in Public Health. Teacher, Department of Nursing of Patos Integrated College, Patos (PB), Brazil.

4 Physiotherapist. Teacher at College Maurício de Nassau, Brazil.

5 Physiotherapist. Master in Public Health. Teacher, Department of Physical Therapy of Patos Integrated College, Patos (PB), Brazil.

6 Physiotherapist. Teacher, Department of Physical Therapy of Patos Integrated College, Patos (PB), Brazil.

7 Odontologist, Doctor in Dental Sciences; Teacher at University Cruzeiro do Sul, Brazil.

Contact information:

Elicarlos Marques Nunes

Address: Rua: Aluisio Cunha Lima, 397. Bairro: Catolé, Campina Grande-PB. CEP: 58410-258.

ほ elicarlosnunes@yahoo.com.br 
was statistically lower compared with the other modalities. Muscle strength was not significantly different between the four modalities of bench press exercise.

Conclusion: In conclusion, muscle strength and electrical activity of the pectoralis major muscle showed no differences between the bench press modalities, except for the electrical activity of the lower part in incline exercise.

\section{Keywords}

Electromyography; Muscle Strength; Isometric

Contraction.

\section{Introduction}

The pectoralis major (PM) is one of the most exercised muscles within the gyms for being considered the most important muscle in the practice of any sport involving the participation of the upper limb, but also for its aesthetic importance in a well defined and bulky chest for men [1].

This muscle is located in the chest and it has the shape of a triangle, with its internal side inserted into the anterior surface of the sternum, into the clavicle and last ribs. By contracting, it depresses the arm when it is high, and when the arm is depressed, the muscle performs the shoulder protrusion movement, bending the back, and it may also elevate the thoracic cage [2].

The origin of the pectoralis major muscle is fixed and it performs the adduction and medial rotation of the humerus, whereas its insertion assists in lifting the chest while performing forced inspiration [3].

The bench press is one of the most used exercises in strength training for the development of the upper trunk musculature, particularly the pectoralis major, deltoid (clavicular part) and triceps brachii muscles. The bench press exercise is very popular, being present in the training of recreational practitioners and athletes from various sports modalities [4]. The aim of the bench press exercise practice in the gyms ranges from therapeutic purposes to muscular hypertrophy, while, in sports modalities, the aim is to improve the performance of muscle strength [5].

Muscle strength is defined as a tension that a muscle or muscle group can exert against a resistance in a maximum effort at a given speed [6]. For the American College of Sports Medicine (ACSM), muscle strength is the maximum amount of tension that can be generated by a muscle or muscle group in order to perform certain movements [7].

To measure the strength exerted by a given muscle, there are several devices, among which the Electromyography (EMG) can be highlighted. Through the auxiliary device called load cell, it measures, in kilograms, the mechanical energy imposed by the muscle [8].

In literature, there are studies involving the practice of physical exercises and the investigation of different positions to improve muscle performance, by measuring the electrical activity through electromyography. However, science still needs other studies to further investigate the information about the relation between muscle recruitment and strength [9-10].

Therefore, this study aimed to analyze the muscle strength and the electrical activity of the pectoralis major muscle during the performance of bench press exercise on a machine in horizontal, incline and decline modalities. 


\section{Methodology}

This research refers to a case study, which experimental data were analyzed quantitatively [11]. From the point of view of its purposes, the research is characterized as exploratory, since it aimed to collect data about a particular element, delimiting a field of work which allows its broad and detailed knowledge and mapping the manifestation conditions of this element [12].

The study was carried out in the Fitness gym belonging to the Integrated Colleges of Patos - FIP, in the city of Patos - PB, during the first semester of 2012 , with the permission of the gym coordinator.

The population consisted of students regularly enrolled in undergraduate courses of Physical Therapy and Physical Education of the Integrated Colleges of Patos (PB) - FIP, which were sampled by convenience, totaling 20 male subjects. All subjects underwent a prior cardiovascular, neuromuscular and flexibility evaluation as a condition to attend the gym.

The study included male subjects aged between 18 to 25 years old, with a standard BMI between 20 and $25 \mathrm{Kg} / \mathrm{cm}^{2}$, normorreactive, with no history of musculoskeletal injuries of the upper limbs and spine, which have shown no irritability to the electrodes and which were subjected to muscle training for at least three months with a minimum attendance of three and maximum of five times a week.

The sample exclusion criteria were subjects who did not agree to sign the Informed Consent Form, subjects who showed irritation to the electrodes or who presented, on the day of collection, pains that prevented the research and individuals who did not attend the pre-established muscle training during data collection.

This study was developed after being submitted to and approved by the Ethics Committee in Research of the State University of Paraíba - UEPB under the number 1660.0.133.000-11, in accordance with Resolution No. 466/12 of the National Health
Council, which rules research ethics directly or indirectly involving human beings [13].

Data relating to strength were collected by using a load cell, which was calibrated for each research subject using a load of $10 \mathrm{~kg}$ and, then, connected to a surface electromyography device, Miotool 400 four-channel system type (Miotec Equipamentos Biomédicos Ltda., Porto Alegre-RS, Brazil) coupled to a laptop computer with 15-inch screen (Compaq computer Corporation, Houston, Texas, USA) and Windows 7 (Microsoft Corporation, NY, USA) operating system.

Anthropometric data were analyzed through an analog scale (Balanças Micheletti, São Paulo-SP, Brazil) with integrated measuring tape. The subjects were positioned on the scale platform, back to the stadiometer and with their heads in the Frankfurt plane.

Data were collected through a muscular performance form by electromyographic reading, developed specifically for this research.

In order to perform the exercises, three back pad positions were used: horizontal bench press machine, $30^{\circ}$-declined and $45^{\circ}$-inclined bench press machines (Physicus Equipamentos Esportivos, Auriflama-SP, Brazil), with fixed bar keeping the same hand spacing during the training.

Before attaching the electrodes to the skin of the subjects, the decrease in skin impedance was performed by abrasive disinfection with $70 \%$ alcohol in the target region, as well as the trichotomy of individuals with excess hair in this region [14].

Then, the electrodes were attached on the center of the pectoralis major muscle (MP) on the clavicular, abdominal and sternocostal parts of the right upper limb, following the recommendation by SENIAM (Surface Electromyography for a Non-Invasive Assessment of Muscles) for attaching them (Hermes et al., 2000), since it is suggested that the electromyographic reading of pectoralis muscle could influence the cardiac activity on the left side. 
The electrodes used were active and self-adhesive disposable electrodes (Maxicor Produtos Médicos, Pinhais-PR, Brazil), composed of adhesive foam, silver rivet $(\mathrm{Ag} / \mathrm{AgCl})$, and a cellulose conductive gel which was solid and protected by a PVC foil.

The electrodes were connected to the electromyograph sensor, and this, in turn, was connected to the laptop, in which the capture, amplification, filtering, analysis, quantification, standardization and storage of the electromyographic signal was performed through Miograph 2.0 software (Miotec Equipamentos Biomédicos Ltda., Porto Alegre-RS, Brazil). After collection, the electrodes used were discarded in a specific location.

Data were subjected to a descriptive statistical analysis, observing the mean and standard deviation of each variable studied, using SPSS Statistics 20 for Windows (IBM, New York, NY, USA) software.

Once the data did not show normal distribution according to the Kolmogorov-Smirnov and Shapiro-Wilk tests, we used the nonparametric test for paired samples. The level of significance was set at 5\% ( $p<0.05)$. Friedman's test and mul-

Table 1. Anthropometric characteristics of the sample $(n=20)$.

\begin{tabular}{|l|c|}
\hline Anthropometric variables & Mean \pm Standard deviation \\
\hline Age (years) & $23.2 \pm 0.9$ \\
\hline Height $(\mathrm{m})$ & $1.7 \pm 0.1$ \\
\hline Weight $(\mathrm{Kg})$ & $77.5 \pm 8.0$ \\
\hline $\mathrm{BMI}(\mathrm{Kg} / \mathrm{cm} 2)$ & $25.1 \pm 2.3$ \\
\hline
\end{tabular}

tiple comparisons test were used to compare the measures of variations in the electrical activity in the upper (clavicular part), medium (sternocostal part) and lower fibers in order to evaluate muscle strength between the maximum load in the horizontal bench press exercise with and without lumbar rectification, and in the incline and decline bench press exercises.

\section{Results}

In Table 1, we observe the anthropometric characteristics of the studied sample. The average age of the participants was 23.2 years old, while the average weight was $77.5 \mathrm{~kg}$. The average height was 1.70 $\mathrm{m}$ and the average BMI was $25.1 \mathrm{Kg} / \mathrm{cm}^{2}$.

The data displayed in Table 2 represent the EMG reading of the pectoralis major, after the normalization of the data obtained during the bench press exercise in its four variations (with and without lumbar rectification, incline and decline positions). The electrical activity was statistically lower in the lower part of the pectoralis major in the incline modality compared with the horizontal (with and without lumbar rectification) and decline modalities. The electrical activity of the clavicular and sternocostal parts of the pectoralis major showed no significant difference in the EMG reading between the four variations of the bench press exercise.

Table 3 shows the comparison of electrical activity between the three parts of the pectoralis major for each bench press modality. The electri-

Table 2. Comparison of the electrical activity of the pectoralis major in the different bench press modalities.

\begin{tabular}{l|c|c|c|c|c|}
\hline \multirow{2}{*}{ Pectoralis Major } & \multicolumn{5}{|c|}{ Mean \pm Standard deviation } \\
\cline { 2 - 7 } & Without rectification & With rectification & Incline & Decline & p \\
\hline Clavicular part & $44.7 \pm 7.3 \mathrm{~A}$ & $44.7 \pm 6.9 \mathrm{~A}$ & $43.2 \pm 6.3 \mathrm{~A}$ & $41.7 \pm 6.9 \mathrm{~A}$ & 0.202 \\
\hline Sternocostal part & $39.3 \pm 7.0 \mathrm{~A}$ & $40.0 \pm 5.8 \mathrm{~A}$ & $40.0 \pm 6.0 \mathrm{~A}$ & $40.1 \pm 8.1 \mathrm{~A}$ & 0.898 \\
\hline Lower part & $41.4 \pm 5.5 \mathrm{~A}$ & $43.2 \pm 6.1 \mathrm{~A}$ & $37.0 \pm 3.6 \mathrm{~B}$ & $43.3 \pm 4.6 \mathrm{~A}$ & $<0.001$ \\
Overall average & $42.0 \pm 2.0$ & $42.0 \pm 2.0$ & $40.0 \pm 2.5$ & $41.7 \pm 1.3$ &
\end{tabular}

* Same letters in the same line do not differ statistically by the Friedman's test and Multiple Comparisons test $(p<0,05)$ 
Table 3. Comparison of the electrical activity of the clavicular, sternocostal and lower parts of the pectoralis major in each bench press modality.

\begin{tabular}{l|c|c|c|c|}
\multirow{2}{*}{ Pectoralis Major } & \multicolumn{4}{|c|}{ Mean \pm Standard deviation } \\
\cline { 2 - 5 } & Without rectification & With rectification & Incline & Decline \\
\hline Clavicular part & $44.7 \pm 7.3 \mathrm{~A}$ & $44.7 \pm 6.9 \mathrm{~A}$ & $43.2 \pm 6.3 \mathrm{~A}$ & $41.7 \pm 6.9 \mathrm{~A}$ \\
\hline Sternocostal part & $39.3 \pm 7.0 \mathrm{~B}$ & $40.0 \pm 5.8 \mathrm{~B}$ & $40.0 \pm 6.0 \mathrm{~B}$ & $40.1 \pm 8.1 \mathrm{~A}$ \\
\hline Lower part & $41.4 \pm 5.5 \mathrm{~A}, \mathrm{~B}$ & $43.2 \pm 6.1 \mathrm{~A}$ & $37.0 \pm 3.6 \mathrm{~B}$ & $43.3 \pm 4.6 \mathrm{~A}$ \\
\hline Overall average & $42.0 \pm 2.0$ & $42.0 \pm 2.0$ & $40.0 \pm 2.5$ & $41.7 \pm 1.3$ \\
\hline $\mathbf{P}$ & 0.022 & 0.002 & $<0.001$ & 0.359 \\
\hline * Same letters in the same column do not differ statistically by the Friedman's test and Multiple Comparisons test. $(p<0,05)$
\end{tabular}

Table 4. Force (Kgf) of the pectoralis major in bench press exercise.

\begin{tabular}{|l|c|c|c|c|c|}
\hline \multirow{2}{*}{ Pectoralis Major } & \multicolumn{4}{|c|}{ Mean \pm Standard deviation } \\
\cline { 2 - 6 } & Without rectification & With rectification & Incline & Decline & p \\
\hline Force $(\mathrm{Kg})$ & $52.7 \pm 16.4 \mathrm{~A}$ & $54.2 \pm 16.7 \mathrm{~A}$ & $49.6 \pm 10.9 \mathrm{~A}$ & $54.0 \pm 13.9 \mathrm{~A}$ & 0.124 \\
\hline & * Same letters in the same line do not differ statistically by the Friedman's test and Multiple Comparisons test. $(\mathrm{p}<0,05)$
\end{tabular}

cal activity was statistically higher in the clavicular part compared with the sternocostal part in the horizontal bench press with and without lumbar rectification and in the incline bench press. There was no difference between the clavicular and lower parts in the horizontal bench press with and without lumbar rectification and between the sternocostal and lower parts in the incline bench press without lumbar rectification. However, in the decline bench press there was no difference in the electrical activity of the three parts of the pectoralis major.

Regarding the strength developed by the pectoralis during Maximal Voluntary Isometric Contraction, no statistically significant differences between the four variations of the bench press exercise were observed. (Table 4)

Regarding strength and electromyographic activity, Figure 1 shows a linear relation between the EMG activity of the pectoralis major muscle in the four bench press modalities and the muscle strength in bench press with and without lumbar rectification.

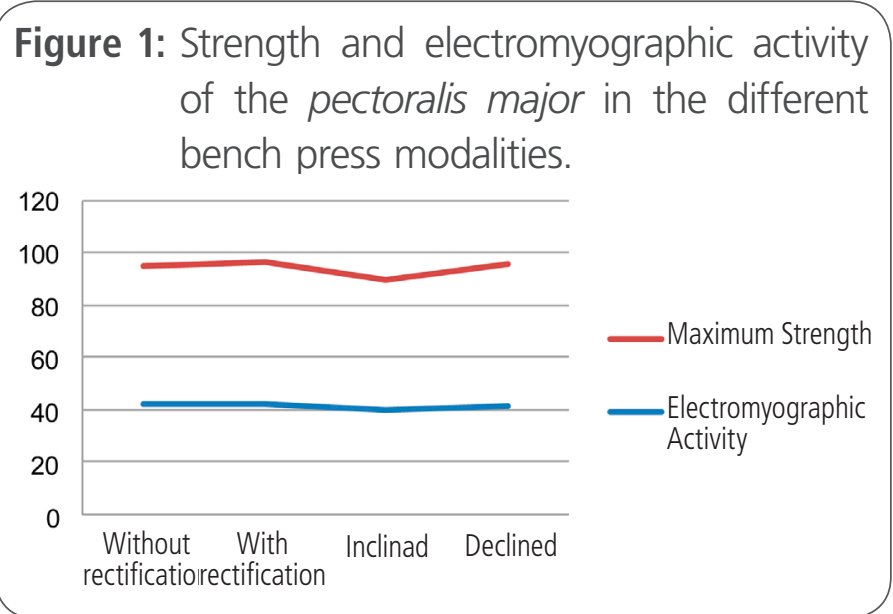

It was found that, as there was a change in the positioning modality, there was a reduction or increase in the maximum strength obtained during the maximal voluntary isometric contraction (muscle strength) produced in incline and decline bench press modalities, respectively.

\section{Discussion}

In the literature, we found few studies on pectoralis major muscle and bench press exercise with 
different methodologies and evaluations, making it difficult to compare the results [15-16]. The bench press was the exercise chosen in this study since it promotes the myoelectric activation of the pectoralis major muscle [17] According to Rocha Júnior et al [15] both horizontal bench press with barbell and crucifix exercise in the machine can be used in training in order to promote stimuli in the pectoralis major, depending on the availability of materials and/or on the specificity of the motor activity which performance is supposed to be improved.

Regarding the upper (clavicular) part of the pectoralis major, no differences in the electrical activity between horizontal, incline and decline bench press modalities were found. These results corroborate the study by Glass and Armstrong [18] in which electromyographic data revealed no significant differences in the activation of the upper part of the pectoralis major between incline and decline bench press. However, in the study by Barnett et al [19], the clavicular part showed a similar activity for the incline and the horizontal bench press and it showed less activity during the decline bench press. Trebs et al [4] observed that the clavicular part showed a significantly higher activity in the incline bench press compared with the horizontal modality. These differences can be explained by the angle of inclination of the exercise and by the hand spacing adopted in the different studies.

In the current study, no significant differences were observed in the electrical activity in the different modalities of bench press exercise. Divergent results were also cited in the study by Treb et al [4], in which the activation of the sternocostal part was significantly higher in the incline bench press compared with horizontal bench press, thus showing that the greater the angle of the exercise, the stronger the activation of this part of the muscle.

It was possible to observe a significant difference in the lower part, with lower values of electrical activity in the incline modality when compared with the other ones. Different results were found by
Glass and Armstrong [18] according to which there was a significant difference when compared with the lower part of the pectoralis major, which was more activated by the decline bench press.

An increase was observed in the electromyographic activity of the clavicular part when compared with the sternocostal part in the horizontal bench press with and without lumbar rectification and in the incline bench press. In the study by Lehman [20], during the supination grip there was an increased activity in the clavicular part of the pectoralis major. Moreover, from the wider to the narrower grip, the author observed a decrease in the sternoclavicular part. In pronation, the change to a narrower grip did not result in a decrease in the activity of the pectoralis major.

Data collected in the study were related to the right upper limb. According to SENIAM's [21] recommendation, it is suggested that the EMG reading of the pectoralis could influence the cardiac activity on the left side. This fact has limited the comparison of the results with other studies. In the study by Roberts et al [9], the electromyographic signal of the pectoralis major muscle was analyzed bilaterally in the incline bench press during the concentric and eccentric phases, with external loads of $25 \%, 50 \%$, $75 \%$ and $100 \%$ of the maximum load.

Regarding the maximum strength achieved in the bench press exercise during Maximal Voluntary Isometric Contraction (MVIC), no statistically significant difference was found between the four bench press exercise modalities. Divergent results were found by Furtado et al [10] and Penido et al [16], which found that the decline bench press was the exercise in which the subjects had higher strength rates, followed by horizontal and incline modalities. According to Kubo et al [22] that fact may be due to differences between the joint angle used for the implementation of the isometric test, which can affect muscle length, muscle activation and, consequently, the production of muscle strength. 
Regarding the horizontal bench press exercise with lumbar arching, i.e. without rectification of the lumbar lordosis, Delavier [23] stated that this position allowed the individuals to pull up substantially heavier loads, and abdominal (or lower) part of the pectoralis major was the most requested one. On the other hand, the author noted that there was less activation of the lower part of the pectoralis major in exercise performed with the lower limbs up, i.e., with lumbar rectification. This statement contradicts the results found in this study, since the strength capacity showed no statistically significant difference between the horizontal bench press with and without lumbar rectification.

Delavier [23] also said that the horizontal bench press exercise performed with lumbar rectification reduces the effort of the lower pectoral, focusing the effort on the sternocostal and clavicular part. This differs from our results, since the electrical activity of the lower part was statistically similar to the clavicular part one, differing only from the sternocostal part, which showed reduced electrical activity.

According to De Luca [24], when the volume of the electrode detection is smaller than the crosssectional area of the active muscle, newly recruited motor units located close to the muscle will proportionately contribute with the increase in the electromyographic signal than the muscle strength, resulting in a curvilinear relation between EMG amplitude and strength. On the other hand, when the detection area is closer to the active cross-sectional area of the muscle, this effect will result in a one to one relation between amplitude and strength, producing a linear relation.

Thus, one should be cautious in claiming that a muscle is stronger because it has higher electromyographic activity. Potney and Roy [25] reported that the electrical activity may be altered by the position of the electrodes, if a displacement of the electrodes occurs through the skin; by the type of contraction and speed of movement which will affect the level of electromyographic activity recorded; and especially when comparisons are made between isometric exercises performed at different joint angles.

It is important to emphasize that several studies have been conducted in order to compare the pectoralis major muscle, the anterior deltoid and triceps brachii, showing the joint action while performing the bench press exercise $[17,20]$. However, in this study, which aim was to evaluate only the strength and electrical activity of the pectoralis major, it was not possible to determine the influence of the anterior deltoid and triceps brachii muscles in the electromyographic activity and in the muscle strength exerted during the bench press exercise, due to the fact that they were not monitored in the experimental stage.

Another point to be considered is the grip on the bar and the hand spacing, since in this study all subjects were in prone position with their hands on the bar in a fixed position. As no comparison between different positions and hand distances were made, the results could be possibly different from those found in this study.

\section{Conclusion}

The electrical activity of the clavicular, sternocostal and lower parts of the pectoralis major muscle showed no statistically significant differences between the different modalities of bench press exercise, except for the lower part in the incline bench press exercise, which was significantly lower when compared with horizontal bench press with and without lumbar rectification and compared with decline bench press.

The electrical activity of the clavicular part was significantly higher when compared with the sternocostal part in the horizontal bench press with and without lumbar rectification and also in the incline bench press, and it was similar when compared to the lower part in the horizontal bench press with 
and without lumbar rectification and also in the decline bench press.

The muscle strength of the pectoralis major showed no significant difference between the horizontal bench press exercise with and without lumbar rectification and the incline and decline modalities.

\section{References}

1. Ferreira AMP. Comparação da eficácia de dois testes de extensões de braços. Análise neuromuscular do Pectoralis Major e do Triceps Brachii. [Monografia]. Coimbra: Universidade de Coimbra; 2005

2. Vigué-Martín J. Atlas do corpo humano. São Paulo: Barsa Planeta, 2007

3. Marques AP. Cadeias musculares: um programa para ensinar avaliação fisioterapêutica global. 2ª ed. São Paulo: Manole, 2005.

4. Trebs AA, Brandenburg JP, Pitney WA. Pitney. An electromyography analysis of 3 muscles surrounding the shoulder joint during the performance of a chest press exercise at several angles. J Strength Condit Res 2010; 24(7): 1925-1930.

5. Marchetti PH, Arruda CC, Segamarchi LF, Soares EG, Ito ST, Luz Junior DA, Pelozo Junior O, Uchida MC. Exercício supino: uma breve revisão sobre os aspectos biomecânicos. Braz J Sports Exercise Res 2010; 1(2): 135-142.

6. Fleck S, Kraemer W. Designing resistance training programs. Champaign; Human Kinetics, 2004.

7. Miranda I. As representações estéticas do corpo feminino: estudo comparativo realizado com mulheres adultas jovens e idosas praticantes de actividade física regular. [Dissertação de Mestrado]. Porto: Universidade do Porto; 2008.

8. Camargo AP. Desenvolvimento de um medidor eletrônico vazão utilizando célula de carga. [Dissertação de Mestrado]. Piracicaba: Universidade de São Paulo; 2009.

9. Rodrigues JA, Büll ML, Dias GA, Gonçalvez M, Guazzelli JF. Electromyographic analysis of the pectoralis major and deltoideus anterior in the inclined "flying" exercise with loads. Electromyogr Clin Neurophysiol 2006; 46 (7-8): 441-448.

10. Furtado ETF, Silva GP, Guimarães MP, Santos TP, Campos YAC, Botelho ERA, Silva AC, Silva SF. Comparação entre valores obtidos a partir do teste de uma repetição máxima para os exercícios supino reto, inclinado e declinado. Rev Digital Efdeportes 2010; 15(144): 1-6.

11. Lakatos EM, Marconi MA. Fundamentos de metodologia científica. $5^{a}$ ed. São Paulo: Atlas, 2008.

12. Severino AJ. Metodologia do trabalho científico. $23^{a}$ ed. São Paulo: Cortez, 2007.

13. Brasil. Ministério da Saúde. Conselho Nacional de Saúde. Comissão Nacional de Ética em Pesquisa (Conep). Resolução n 196/96 sobre pesquisas envolvendo seres humanos. Brasília, 1996.
14. Gonzalez Al, Del Castanhel A, Comim CM, Souza KO, Tuon L. Utilização da EMG de superfície como método de análise de força muscular e função respiratória em portadores de distrofinopatias. Fisioter Bras 2006; 7(4): 118-123.

15. Rocha Júnior VA, Gentil P, Oliveira E, Carmo J. Comparação entre a atividade EMG do peitoral maior, deltóide anterior e tríceps braquial durante os exercícios supino reto e crucifixo. Rev Bras Med Esporte 2007; 13(1): 51-54

16. Penido LNA, Carvalho RES, Pereira FD, Oliveira RAA, Silva AC, Silva SF. Comparação entre força máxima muscular isométrica dinâmica em três diferentes ângulos do exercício supino. Rev Acta Bras Mov Hum 2012; 2(1): 24-33.

17. Cacchio A, Don R, Ranavolo A, Guerra E, McCaw ST, Procaccianti R, Camerota F, Frascarelli M, Santilli V. Effects of 8-week strength training with two models of chest press machines on muscular activity pattern and strength. J Electromyogr Kinesiol 2008; 18(4): 618-627.

18. Glass SC, Armstrong T. Electromyographical activity of the pectoralis muscle during incline and decline bench presses. J Strength Cond Res 1997; 11(3): 163-167.

19. Barnett $C$, Kippers $V$, Turner P. Effects of variation of the bench press exercise on the EMG activity of five shoulder muscles. J Strength Cond Res 1995; 9(4): 222-227.

20. Lehman GJ. The influence of grip width and forearm pronation/ supination on upper-body myoelectric activity during the flat bench press. J Strength Cond Res 2005; 19(3): 587-591.

21. Hermens HJ, Freriks B, Merletti R, Hägg G, Stegeman D, Blok J, Rau G. European recommendations for surface electromyography, results of the SENIAM project. Enschede: Roessingh Research and Development b.v., 1999.

22. Kubo K, Tsunoda N, Kanehisa H, Fukunaga T. Activation of agonist and antagonist muscles at different joint angles during maximal isometric efforts. Eur J Appl Physiol 2004; 91(2-3): 349352

23. Delavier F. Guia dos movimentos de musculação: abordagem anatômica. $3^{\mathrm{a}}$ ed. São Paulo: Manole, 2002.

24. De Luca CJ. The use of surface electromyography in biomechanics. J Appl Biomech 1997; 13: 135-163.

25. Potney LG, Roy SH. Eletromiografia e testes de velocidade de condução nervosa. In: O'Sullivan SB, Schmitz TJ. Fisioterapia: avaliação e tratamento. 5a ed. Barueri: Manole, 2010.

\section{Publish in International Archives of Medicine}

International Archives of Medicine is an open access journal publishing articles encompassing all aspects of medical science and clinical practice. IAM is considered a megajournal with independent sections on all areas of medicine. IAM is a really international journal with authors and board members from all around the world. The journal is widely indexed and classified Q1 in category Medicine. 